Tryuk, M. (2016). Interpreting and translating in Nazi concentration camps during World War II. Linguistica Antverpiensia, New Series: Themes in Translation Studies, 15, 121-141.

\title{
Interpreting and translating in Nazi concentration camps during World War II
}

\section{Malgorzata Tryuk}

University of Warsaw, Poland

m.tryuk@uw.edu.pl

This article investigates translation and interpreting in a conflict situation with reference to the Nazi concentration camps during World War II. In particular, it examines the need for such services and the duties and the tasks the translators and the interpreters were forced to execute. It is based on archival material, in particular the recollections and the statements of former inmates collected in the archives of concentration camps. The ontological narratives are compared with the cinematic figure of Marta Weiss, a camp interpreter, as presented in the docudrama "Ostatni Etap" ("The last Stage") of 1948 by the Polish director Wanda Jakubowska, herself a former prisoner of the concentration camp. The article contributes to the discussion on the role that translators and interpreters play in extreme and violent situations when the ethics of interpreting and translation loses its power and the generally accepted norms and standards are no longer applicable.

\section{Introduction}

Studies on the roles of translators and interpreters in conflict situations have been undertaken by numerous scholars since 1980. They have produced valuable insights into the subject which include various types of study of an empirical, analytical or theoretical nature (Baker \& Maier, 2011). These studies encompass, inter alia, reports on interpreting at the trials of the Nazi war criminals in Nuremberg (Bowen \& Bowen, 1985; Gaiba, 1998); in the Tokyo War Crimes Tribunal for Far East (Takeda, 2007; Watanabe, 2009), at Eichmann's trial in Jerusalem (Morris, 1998); at the hearings conducted by the Truth and Reconciliation Commission in South Africa (Wiegand, 2000) and before the International Criminal Tribunal for Rwanda (Haas, 2011); at the UNO peace missions in Lebanon and the countries of the former Yugoslavia (Thomas, 1997); and in the humanitarian missions of NGOs as well as in the armed conflicts in Iraq and Afghanistan (Arciszewska, 2013; Capelli, 2014; Guidère, 2008; Stahuljak, 2000, 2010; Szymczukiewicz, 2005). Scholars who have done research on empirical and theoretical aspects of translation and interpreting have tried to reveal the ethical norms binding on a translator and an interpreter in his or her work. These norms are deontological and 
sui generis and include: reliability, morals beyond reproach, linguistic competence and expertise, faithfulness in translation and interpreting, impartiality and neutrality, awareness of social and cultural particularities, a high resistance to stress, and observance of the rules of professional ethics. Among these norms, impartiality and/or neutrality are usually assigned primary importance and most studies emphasize that, above all, an interpreter is expected to be accurate and impartial (Hale, 2007). This means that translators and interpreters are expected to be neutral with respect to the discourse and the persons for whom they interpret or translate.

In circumstances such as war or armed conflict, the tasks undertaken by the interpreter or translator significantly exceed the transmission of messages from one language to another. What is more, interpreters, when discharging their duties, are not always aware of all the possible consequences of their activities. This discordance between the principles of neutrality, impartiality, non-involvement and professionalism laid down in codes of professional ethics, on the one hand, and the actual activities of the translator or interpreter in conflict situations, on the other, is well known. Ethical issues, consistently hidden behind a screen of rules formulated in the codes, are one of the crucial problems of translation and interpreting studies (Baker \& Maier, 2011). They also constitute the main focus of the present article, which is dedicated to translators and interpreters in the extreme situations imposed by the events of World War II.

The aim of this article is to study Nazi concentration camp records, and in particular the recollections of former prisoners, in order to analyse the activities of the Lagerdolmetscher, the camp interpreter.

The ethical norms for interpreting that are generally accepted today were not applicable to the concentration camps back then, as there were neither norms nor standards of any kind applicable in such circumstances. In particular, I investigate why the interpreters were needed, who they were, how they were recruited for the job, what their duties were, how they performed their duties, and what their roles were.

This article is based mainly on the authentic recollections of former extermination and concentration camp inmates which have been collected in the Auschwitz-Birkenau Memorial and Museum Archives, the Majdanek Museum Archives and the archives of the Memorial Museum in Dachau. This material is a unique example of the ontological narratives which recount the experiences of the victims of the Nazi regime (Kuhiwczak, 2007). It presents accounts of the inmates' arrest, their life and the possibility of survival in the camps, their relationships with fellow prisoners, and their fear of the SS and other camp functionaries. Despite the massive amount of material, it should be noted that references to interpreting or translating per se are scant, and when they do occur they tend to be random and laconic, usually consisting of dry facts. In addition, inmates sometimes offer differing versions of the 
same event. For these reasons, obtaining an objective, empirical account of events is virtually impossible. The narratives of victims of the Nazi regime as related by them in their records are compared with the figure of Marta Weiss, a camp interpreter, as presented in the feature film The Last Stage (in Polish Ostatni etap) of 1948 by the Polish director Wanda Jakubowska, who herself was a prisoner in the concentration camps for women in Auschwitz-Birkenau (registration number 43513) and in Ravensbrück. Both the narratives of former inmates and the language of the film constitute the basis of the analysis of the roles of camp interpreters in an unprecedented environment of violent conflict.

\section{Interpreters in ontological narratives on concentration camps}

\subsection{Multilingualism in concentration camps}

In each Nazi concentration camp the inmates represented between 35 and 40 different national or ethnic groups, each with their own language. All the inmates lived in extreme conditions, with the German language ever present and dominating. Communication, if any, with the SS guards or a kapo (a prisoner functionary) had to be in German. If any postal services were allowed at all, all the paperwork had to be in German. In the barracks and work blocks all rules, orders and directions were delivered in German. In concentration camp (in German Konzentrationslager or KL) Auschwitz the use of the languages of the inmates (such as Polish, Czech, Russian, Italian or French) was forbidden. There was one official language in all the concentration camps: German. Every inmate was required to memorize some basic phrases in German: their camp detention number, their barrack number and the lyrics of songs they were required to sing for the amusement of their guards. In a few instances only were certain signs posted in both Polish and German, for example "Halt! Stój!"' (Tryuk, 2016). Survival in the concentration camp without some knowledge of German was practically impossible and there are many statements proving that this was an everyday reality, as described by Primo Levi:

The greater part of the prisoners who did not understand German that is, almost all the Italians - died during the first ten to fifteenth day after their arrival: at first glance, from hunger, cold, fatigue, and disease; but after a more attentive examination, due to insufficient information. If they had been able to communicate with their more experienced companions, they would have been able to orient themselves better: to learn first of all how to procure clothing, shoes, illegal food, how to avoid the harsher labour and the often lethal encounters with the SS, how to handle the 
inevitable illness without making fatal mistakes. I don't want to say that they would not have died, but they would have lived longer and had a greater chance of regaining lost ground (Levi, 1989, p. 93).

However, in reality, two languages were used in the camps: German and lagerszpracha, which was created out of Polish, Yiddish, the Silesian dialect, Hungarian or any other language spoken in a particular camp. It was camp jargon - a way for the inmates coming from all over Europe to communicate among themselves (Gunia, 2006; Gramling, 2012; Levi, 1989; Wesołowska, 1996). Occasionally, it also occurred that some German functionaries and even SS troops would use some expressions from lagerszpracha. There was also another "language" in widespread use in the camps: beatings and the whip, as evidenced in the quotation by Lore Shelley (1986, p. 363), who recalls the SS-Unterscharführer Karl Broch in KL Auschwitz saying that: "Die Peitsche ist der beste Dolmetscher, sie spricht alle Sprachen" [The whip is the best interpreter; it speaks all languages].

\subsection{Interpreting and translation in concentration camps}

As in any other multilingual situation, in the concentration camps there was a need for translators and interpreters. In KL Auschwitz, upon arrival in the camp, a number of inmates listed their profession as "interpreter" (Dolmetscher). These declarations can be found in the registration documents of new arrivals to the death camps which are kept in the archives of the former camps. In the majority of cases the persons declaring themselves to be interpreters were Jews born in Poland or Russia, often transported to the camps from France or Belgium. Very few of them survived. One of the inmates who declared the profession of an interpreter upon arrival in the camp was a young Polish-born Jew, Mala Zimetbaum, who continued this "job" in the camp.

In the KL Auschwitz three groups of people acting as interpreters can be differentiated. The first group consisted of the SS men working in the Politische Abteilung (camp administration and Gestapo) in the camp, often Volksdeutsche ${ }^{1}$ or Silesians fluent in Polish and employing Polish during the initial interrogations. Shelley (1986) quotes a number of SS members who were used as interpreters in KL Auschwitz and among them were Klaus Dylewski or Gerard Lachman. A second large group consisted of female inmates working in the Politische Abteilung as registrars (Schreiberinen) or messengers (Läuferinen). One of them was Raya Kagan, who years later testified as a witness at the Eichmann trial in Jerusalem in 1960 (Arendt, 1963; Shelley, 1986, p. 280). These interpreters were mostly Slovak or Hungarian Jews. Owing to the nature of their duties, Lore Shelley (1986) notes that they later referred to 
themselves as Secretaries of Death. They worked in different sections of the camp administration, that is, in the Secretariat and Interrogation, Civil, Legal and Reception Sections. The third group of interpreters that can be identified was made up of prisoners who declared they knew German (or another language necessary in the camp, such as Russian in the KL Majdanek). They were singled out as interpreters - Dolmetscher. In fact, these interpreters often had to perform their function despite the fact they were treated like all other inmates - in addition to other exhausting work forced upon them. Their interpreting duties did not guarantee them any privileges in terms of how they were treated - for example, they received no additional food rations. Nor did it guarantee them survival. Their knowledge of German did, however, give them access to information and enabled them to communicate better with other inmate functionaries, and in addition simply allowed them to help others. Like other functionaries in the camp, interpreters wore an armband on their striped prison uniforms. Jerzy Poźmiński (APMA-B, vol. 82, p. 2) recalled it as a white brassard with black letters reading "Dolmetscher". However, Tadeusz Paczuła (APMA-B, vol. 111) wrote: "The Lagerdolmetscher wore a black armband" (p. 155). ${ }^{2}$ Interpreters were present in all the commando buildings where the prisoners worked, in each block, in the quarantine area and in the camp hospital (Revier). In addition to their interpreting duties, they served as camp or block registrar and were responsible for order in their respective block.

In each concentration camp there was also a separate function of the chief camp interpreter (or Lagerdolmetscher). Stanisław Skibicki (APMA-B, vol. 149) wrote in his statement: "The camp Commandant communicated with us using interpreters as intermediaries" (p. 99). The function of the Lagerdolmetscher was not introduced in all the camps in the same way. In KL Auschwitz the function of interpreter was established from the very beginning of the camp's existence in 1940; this was also the case at KL Majdanek (Muszkat, APMM VII-135/251). It was different, though, in the camps situated in Germany or Austria. In KL Dachau, the function of the camp interpreters was created only after 1942 (Dobosiewicz, 2000 ; Malak, 1961; Musioł, 1971). For this reason, it is not easy to present a general picture of those who were chosen to act as interpreters in the concentration camps, which constituted a very specific type of multilingual conglomerate with German as the dominant language.

In the KL Auschwitz the function of Lagerdolmetscher was fulfilled by the following persons:

- Władysław Baworowski (registration number 863) - a Polish aristocrat, often cited in the recollections and statements of former inmates as the first camp interpreter, who died in 1942 of hunger and exhaustion; the tragic death of Baworowski is recalled in numerous statements by former inmates; 
- Leonard Belewski (registration number 15586), released from the camp in 1942;

- Franciszek Galus/Kalus (registration number 1000), not well regarded in the memory of former inmates, released from the camp;

- Józef Baltaziński/Balasiński (registration number 749), who zealously carried out all the guards' orders; his inhumane treatment of young inmates is recalled in many records found in the Auschwitz archives;

- Kurt Machula (registration number 12355), from Katowice, released from the camp in 1944;

- $\quad$ Egbert Skowron (registration number 8036), from Warsaw with a perfect command of German, who was helpful to the inmates;

- $\quad$ Łukasz Łukawiecki (registration number 80231), who was the last camp interpreter in Auschwitz at the time of the final evacuation of the camp (Tryuk, 2015, pp. 76-77).

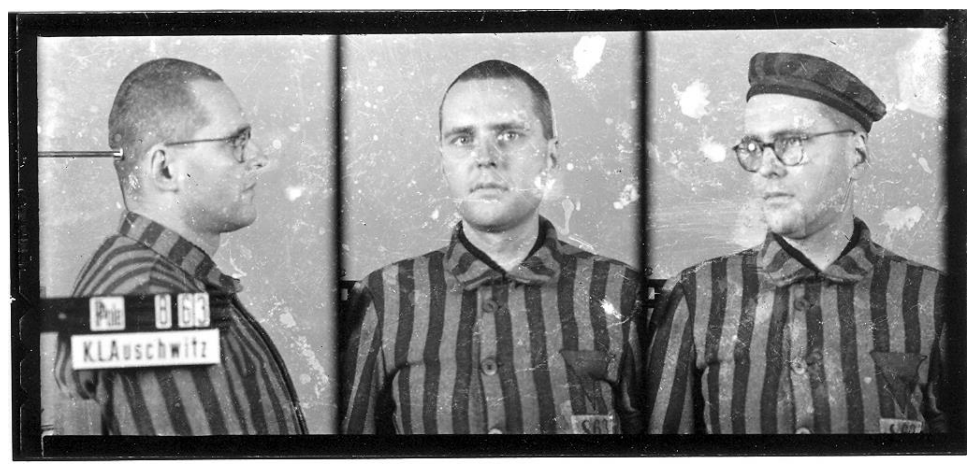

Figure 1: Władysław Baworowski. Courtesy of the Archives of the Auschwitz-Birkenau Memorial and Museum

The names of camp interpreters in other concentration camps feature in numerous recollections and memoirs of former inmates. In KL Dachau, the camp interpreters were Ryszard Knosała, who died of typhus in February 1945, a few months before the liberation of the camp, and Jan Domagała. In KL Mauthausen, the camp interpreters were Pawel Jasieczek, Stanisław Nogaj and Kazimierz Odrobny. In the concentration camp of Majdanek, which was designed primarily as a camp for Russian prisoners of war (Kriegsgefangenenlager der Waffen SS Lublin or KGL Lublin), the interpreters were Krzysztof Radziwiłl, Iwan Bielski, Bargelski, Brzezowski, Janusz Wolski, Czesław Kulesza, Żurawski and Michał Gumiński (Tryuk, 2015).

The interpreters were assigned and designated ex officio or were chosen from among the prisoners. There is little hard evidence concerning 
the process for choosing them, although there are some references in the inmates' recollections. For example, Józef Kret wrote:

I remember during my stay in the Auschwitz camp that in the early days of October there was an announcement during the roll call for all inmates knowing Russian and German to gather in front of barrack block nr. 25 following the roll call. About 100 inmates showed up and were organized into a line, after which they were led in, several at a time, to one of the rooms in the building. There they were examined in German and Russian by a "Lagerdolmetscher" committee, consisting of two inmates and one SS officer. When the exam was over the results were announced and 25 inmates, including me, were deemed to have "passed". We were told to remain in the camp. During this time I heard that we were to join the transport of Russian prisoners of war and act as interpreters (APMA-B, vol. 4, pp. 431-433).

The designation of interpreters could also be done in a different, more direct way. Antoni Wolf, interpreter and Blockschreiber (registrar in the barrack) in the KL Majdanek, recalls that:

On 18 January 1943 [...] at about 9 p.m. the door opened suddenly and four male figures with torches and whips rushed in. They were the kapos Schmuck and Wyderka, accompanied by a small boy, the so-called interpreter known by the name of Bubi. They were boozed up. They came to announce the rules and regulations to be followed in the camp. They requested the interpreter, who, after the first incorrectly interpreted sentence, was slapped on his face, and warned: "I'll knock you into the next world for such interpretation." Then they requested another interpreter [...] "I will interpret," I declared in German. [...] I put a lot of effort in interpreting as simply and comprehensibly as possible [...] I presented our "Lords of life and death" and summarized the provisions of the rules and regulations. They accused me of making the sentences shorter than they actually were in German but I answered them that we, the Poles, do not need long explanations, we instantly understand our situation and presume that we can adapt to the prevailing conditions. The kapo Schmuck liked my answer and announced, "You will be a 'dolmeczer' [interpreter] here and responsible for the order in the block" (Wolf, 2011, p.76).

In KL Auschwitz, there were primarily German-Polish interpreters and a group of multilingual young Jewish girls who interpreted during the interrogations of Polish, Czech, Slovakian, and Hungarian inmates and Russian or Ukrainian POW. Inasmuch as the inmates were predominantly Polish, the primary need was for interpreters working from German into 
Polish. Nevertheless, a review of the records contained in the archives also shows references to other language combinations - for example, from German into French or Czech. Jakub Maestro, a young Jew from Thessaloniki interpreted from German into Greek, French, Romanian and Spanish, and to Polish, which he learned in the camp (Tryuk, 2015).

The situation in KL Majdanek was different. From the very beginning the camp's existence - in November 1941 - groups of prisoners were being transported to Majdanek from other concentration camps such as Dachau, Sachsenhausen, Buchenwald, Dora, Neuengamme, Mauthausen, Gusen and Gross Rosen and they consisted mostly of prisoner functionaries, among whom were physicians and translators/interpreters. In particular, interpreters were needed for German into Russian. Most of them were Polish or German inmates.

The duties of the interpreters included assisting at hearings, acting as camp registrar or messenger, and other tasks such as translating the letters of inmates into German. The interpreters were required during the arrival of new prisoners at the camp, when prisoners were punished or when inmates were "accommodated" in barracks. But, most importantly, the Lagerdolmetscher had to interpret the "welcoming speech" given to the new inmates by the camp commandant. As recalled by one of the former inmates of KL Auschwitz, Czesław Rychlik:

First there was a speech by the Commandant of the camp. His speech was translated by Baworowski. Pointing to the crematorium chimney, he explained to us that that was the only way out of the camp. Whether we lived longer or shorter depended on how hard we worked and our strict obedience to camp regulations (APMAB, vol. 26a, p. 57).

At this particular moment, standing in front of terrorized prisoners, the interpreter was the only one who understood exactly what was meant by "the only way out was through the chimney" and what the fatal fate of the prisoners would be. Baworowski was present at and interpreted a number of punishments and sentences handed down to the inmates. Henryk Król recalls the following incident in this statement:

Following the escape of a prisoner, the interpreter - Baworowski translated to us the punishment announced by the Camp Commander: "You will remain standing for three days and three nights without food or water" (APMA-B, vol. 76, p. 199).

Sometimes, the interpreter's help was invaluable, even to the point of saving the lives of other inmates. As Alfred Wilk remembered:

The day after Christmas Eve (or maybe it was another day) an inmate appeared at the gate, wishing to speak with the Lagerführer. The interpreter who was present, the inmate Baworowski - quickly 
realized that the matter was of great importance. He tried to get the inmate to explain to him why he so badly wished to see the Lagerführer. The inmate did not want to reveal his reasons; he even became threatening. I don't know what arguments Baworowski used, but in the end he learned the truth of the matter. The inmate was wandering around near the kitchen on Christmas Eve and heard other inmates singing the Polish national anthem and this is what he wanted to report to the Lagerführer. He was counting on a favour in return. When Baworowski learned the truth, he told the appropriate person and the traitor was finished off during the night by Brodniewicz or the kapo Arno. It was a very sad incident, and if Baworowski hadn't intervened, many inmates would have lost their lives [...] (APMA-B, vol. 78, p. 1078).

Another example of a courageous act by the Lagerdolmetscher was recalled by Stanisław Charulski:

We also went to Industriehof, and later to the warehouses on Bauhof. The inmate employed there as a registrar was Egbert Skowron, who had been transported to the camp with me. Before being assigned the function of registrar he had been a camp interpreter, since he was fluent in German. Skowron shielded a number of inmates from the dangerous kapo of Industriehof, August. He managed to keep sick inmates away from hard physical labour. In addition on several occasions I was able to organize additional coal supplies using the same delivery receipt. I would exchange the coal with the other blocks in exchange for bread and second helpings for my French and other starving colleagues (APMA-B, vol. 79, p. 132).

Julian Grabski recalls in his statement:

In 1942 I came down with spotted typhus and was taken to the hospital. I managed to get out early and escape the line-up for selection to the gas chamber. I learned about the line-up from Kurt Machula - the camp interpreter (APMA-B, vol. 65, p. 137).

The interpreters helped other inmates without knowledge of German in their communication with their families, as described by Nikodem Pieszczoch:

They [the musicians - MT] were brought to the Blockführerstube, where the interpreter, count Baworowski dictated to the candidates for the orchestra a letter they were to send to their families with a request for musical instruments (APMA-B, vol. 72, p. 14). 
In the light of the sparse data available, we know little about the techniques employed by the interpreters. Kazimierz Hałgas (APMA-B, vol. 89, p. 174) writes that: "Lagerführer Fritzsch spoke to us from the steps of our barracks. His words were translated word for word by Count Baworowski." Most likely the translation consisted of short and brusque military-like orders being rendered into Polish one sentence in a time. In his recollections, Henryk Malak (1961, pp. 304-305) describes Ryszard Knosała, interpreting at an interrogation by a SS captain in KL Dachau, as someone speaking "with a broken, colourless voice" [...]. And he adds, bitterly: "How many orders, how many sentences he had to interpret from the SS tongue into Polish or other languages".

\section{Cinematic representation of the interpreter in a concentration} camp

\subsection{The Last Stage by Wanda Jakubowska (1948)}

Polish director Wanda Jakubowska (1907-1998) filmed The Last Stage back in 1948. In an interview with Barbara Hollender (1987), Jakubowska admitted that she had planned to make a film about Auschwitz during her deportation. Jakubowska's name is almost exclusively associated with this film, despite the fact that she has directed 13 feature films and her career spanned almost 50 years. The film marked the birth of Polish post-war cinema. It had more than 7.8 million viewers and it was exported to dozens of countries. At the Third Karlovy Vary International Film Festival in 1948 The Last Stage was awarded the Grand Prix. For film studies scholars (e.g., Balázs, 1987) The Last Stage is one the first docudramas ${ }^{3}$ in world cinematography. It shows historical facts, the dialogues include the actual words of real-life persons and in general it is filmed in the actual location in which the historical events took place. The Last Stage depicts the monstrosity of KL Auschwitz-Birkenau and drew on Jakubowska's first-hand experiences to portray a concentration camp which was in fact a "factory of death". Jakubowska intended her film to be based exclusively on authentic events witnessed either by herself or by her fellow inmates. To reflect the reality of the camp, the ever-present mud, the shabby barracks surrounded by barbed wire and the heavy pall of smoke over the crematorium, she decided to produce her film on location in the former camp of Auschwitz. She made the film with the participation of the local population. Several episodic roles were played by the camp's former inmates, who were forced to live their Auschwitz experiences for a second time. The film's team made their home in the former SS quarters in the former camp (Haltof, 2012).

To this day, The Last Stage remains a "definitive film about Auschwitz", a prototype for future Holocaust cinematic narratives (Haltof, 2012). The Last Stage is also called "the mother of all Holocaust 
films" (Loewy, 2004), as it establishes several images easily discernible in later narratives on the Holocaust: the dark, realistic images of the camp, the passionate moralistic appeal, and the clear divisions between victims and oppressors.

At the same time, The Last Stage is considered to be a leading film for feminist studies for two reasons at least. First, the authors of the film were women: the scenario was written by the director Wanda Jakubowska together with another fellow inmate, German communist Gerda Schneider. The main characters in the film are almost exclusively women. They form an international group of inmates opposed to female guards and kapo. Their fate as women, the feminity, labour and motherhood in the camp, their solidarity and finally their resistance to the oppressors constitute the topic of the film (Talarczyk-Gubała, 2015).

The Last Stage opens with a brief, quasi-documentary scene of a German raid on a street in Warsaw, which results in the arrest of several people, including one of the film's leading characters (Helena). The next scene moves the action to the camp by portraying a train loaded with Polish Jews arriving at the camp, late at night, the selection of prisoners, the procedure which follows their arrival (the unclothing, the shaving of the hair, the tattooing, the accommodation in barracks). The main part of the film takes place in the Revier (camp hospital) for female inmates, where three groups of people are shown: the victims (inmates), the functionaries (kapos) and the Nazis. Throughout The Last Stage Jakubowska depicts the nightmarish conditions in Auschwitz: recurrent roll calls, random executions and selections, images of powerless people being herded to the gas chambers, and the terrifying efficiency of the camp run by SS guards and camp administrators, both groups portrayed as the embodiment of evil. The ubiquitous terror is stressed by merry music played by the camp orchestra to mark all the tragic moments in the inmates' lives: the way to work, the selection, the executions.

Wanda Jakubowska's objective is also to show the women's solidarity in their suffering as well as in their struggle against fascism. Jakubowska focuses on carefully chosen female inmates, mostly communists and supporters of the communist resistance in the camp, who represented different oppressed nationalities and groups of people. The Auschwitz Babel of tongues is chiefly represented by a number of characters: two Russian inmates, Eugenia the physician and Nadia the nurse; Anna, a German nurse; Helena, a Polish woman who lost her newborn baby in the camp, killed by phenol injection by the German doctor; Michèle, a French résistante; Dessa, a Serb woman prisoner of war; a nameless Gypsy singer and, finally, Marta Weiss, the interpreter. 


\subsection{The interpreter, Marta Weiss}

The main figure who guides the spectators through the inferno of Auschwitz is the interpreter, Marta Weiss. As depicted by Hanno Loewy (2004), Marta is a Polish Jew who, thanks to her linguistic skills, is appointed interpreter by the commandant of the camp. She understands all the languages and she can speak to anyone in the camp - to the inmates as well as to the guards. She can be addressed to by any prisoner, by anyone who has something to say. In the film, she speaks Polish, German, French and Serbo-Croatian. Marta Weiss interprets not only languages but also camp life and the Holocaust, from the first to the last scene of the film. It is she who is asked to by her mother at the arrival of the camp: "Marta, stuchaj, co to jest, gdzie my jesteśmy?" [Marta, listen, what is it, where are we?] (12'50). It is also Marta who utters the last words of the film, seconds before she dies: "Nie pozwólcie, aby Auschwitz się powtórzyl" [You must not let Auschwitz be repeated]. "Nie powtórzy" [It will not be repeated], responds Helena, who is holding her dying friend in her arms (1'44'09).

According to Haltof (2012), the character of Marta Weiss was modelled on Mala (Malka) Zimetbaum (1919-1944), a Polish-born Jew, a KL Auschwitz inmate with the number 19880. As she was fluent in several languages, she soon became an interpreter in the camp. She also played an active part in the camp's resistance. She was remembered by many witnesses for both her spirit and her assistance to other prisoners. In June 1944, she escaped from the camp with a Polish prisoner, Edward (Edek) Galiński (1923-1944), registration number 531. They were caught and hanged in a public execution at the camp. Primo Levi gives the following testimony of Mala Zimetbaum's life and death in Auschwitz:

[...] In Birkenau she acted as an interpreter and messenger and as such enjoyed a certain freedom of movement. She was generous and courageous; she had helped many other companions and was loved by all of them. In the summer of 1944 she decided to escape with Edek, a Polish political prisoner. She not only wanted to reconquer her own freedom: she was also planning to document the daily massacre at Birkenau [...] [After her capture] Mala had resolved to die her own death. While she was waiting in a cell to be interrogated, a companion was able to approach her and asked her, "How are things, Mala?" She answered: "Things are always fine with me." She had managed to conceal a razor blade on her body. At the foot of the gallows, she cut the artery on one of her wrists, the SS who acted as executioners tried to snatch the blade from her and Mala, under the eyes of all the women in the camp, slapped his face with the bloodied hand. Enraged, other guards immediately came running: a prisoner, a Jewess, a woman, had dared defy them! They trampled her to death; she expired, 
fortunately for her, on the cart taking her to the crematorium (Levi, 1989, p. 156).

Marta volunteers to interpret from the very beginning of her stay in the camp. When the train stops at night in an unknown place, which is KL Auschwitz, and the group of terrorized Jews descends from the train, she hears the words of the Lagerkommendant, Hans Schmidt:

SS man: Es ist kein Grund zur Angst und Aufregung vorhanden. Ich bitte, daß ihr meinen Anweisungen der SS ruhig Folge leistet.

[There is no need to be frightened or nervous. I ask you to fulfil calmly my SS instructions.]

Instantaneously Marta begins to interpret:

Marta: On mówi, że nie mamy się czego bać. Mamy spokojnie robić to, co nam każą.

[He says we should not worry. We should do in calm what they tell us to do.]

SS man: Die Trennung muß stattfinden, da wir nicht alle in einem Lager unterbringen können. Die alten Leute und Frauen mit Kindern kommen in ein anderes Lager, während die jungen und gesunden hier bleiben.

[You should split up because we cannot house you in one camp. Old people and women with children go to another camp, while the young men and the healthy stay here.]

Marta: Mamy się rozdzielić. Nie mogą nas wszystkich pomieścić w jednym obozie.

[We must split up. They cannot house us in one camp.]

SS man: Ich verspreche euch, daß ihr euch alle bald wiedersehen werdet.

[I promise you, you will soon see each other again.]

Marta: Obiecuje nam, że niedługo wszyscy się razem spotkacie.

[He promises you will soon meet each other again.]

At that moment the SS man turns to Marta in anger and asks her:

SS man [to Marta]: Was halten Sie für einen Vortrag?

[What are you talking about?]

Marta: Die Menschen verstehen nicht Deutsch und ich übersetze, was Sie gesagt haben.

[People do not understand German. I translate what you said.]

SS man: Ach so. Sprechen und schreiben Sie fließend Deutsch?

[Oh yes. Do you speak and write fluently in German?]

Marta: Ja.

[Yes.]

SS man: Gut! Ich brauche eine Dolmetscherin. Sie werden bei mir arbeiten. Sie gehen danach da drüben!

[Good! I need an interpreter. You will work for me. You will go to the other side]. 
An old man [to Marta]: Co on mówil, czego on od ciebie chciał?

[What did he say? What did he want from you?]

Marta: Powiedział, że będę pracować jako thumaczka.

[He said I would work as an interpreter ](14'57-16'10).

Later, during the accommodation of the new arrivals in the barracks, she is confirmed in her duties as an interpreter:

Prisoner functionary: Gdzie jest tlumaczka?

[Where is the interpreter?]

Marta: Ich bin.

[I am..]

Prisoner functionary: Zatrzymasz włosy, dostaniesz cywilne ubranie. Chodź tutaj.

[You will keep your hair, and you will be given civilian clothes. Come here.]

After the tattooing, when she receives the number 14111, Marta is told to go to the barrack interpreter:

Inmate [to Marta]: Chodź, zaprowadzę cię na blok.

[Come, I will show you the barracks ](19'27).

Marta differs by her clothing from other inmates in striped dresses and headscarfs. She wears a jacket with a strip on her back and a black armband with the inscription "Dolmetscher".

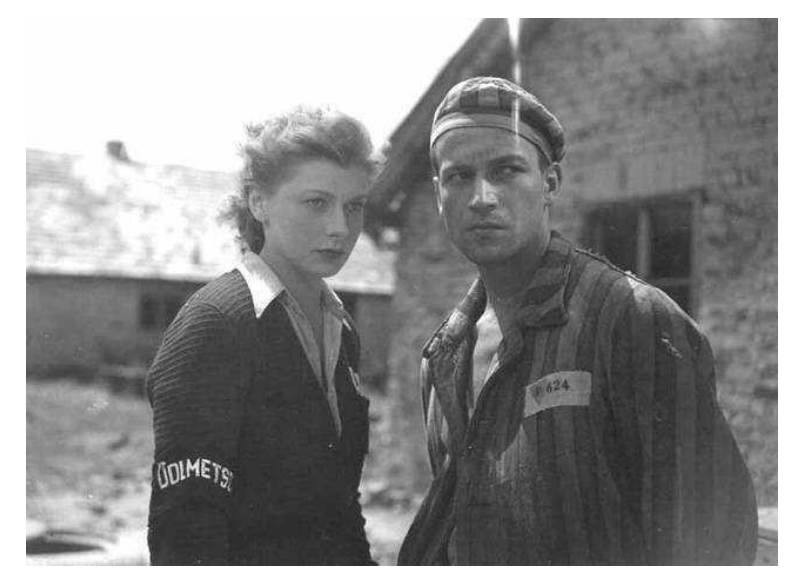

Figure 2: The interpreter Marta Weiss, The Last Stage (1948) 
While walking to the barracks, she is confronted with the horror of the camp reality:

Marta: Co to jest, to, to człowiek?

[What is it? Is it a man?]

Inmate: To muzułmanin na drucie elektrycznym.

[It is a muselmann ${ }^{4}$ on the barbed wire.]

Marta: Muzułmanin?

[A muselmann?]

Inmate: Nie zadawaj naiwnych pytań. Muzułmanin to taka co więcej nie może.

[Don't ask naive questions. A muselmann is somebody who cannot do more.]

Marta: A to, co to za fabryka?

[And this, is it a factory?]

Inmate: Fabryka? To krematorium, gdzie się pali ludzi. Teraz właśnie palą się ci, którzy z tobą przyjechali. Miałaś rodzinę? Głupstwo. Pewnego dnia i tak wszystkie pojedziemy przez komin i wtedy na pewno się spotkamy.

[A factory? It is the crematorium, where they burn people. Now they burn those who arrived with you. Did you have a family? It's no big deal. One day we will all go through the chimney and we will all meet for sure ](19’58-20’23).

Marta is present in the life of the inmates. At all times she tries to ease their misery. She intervenes when the sadistic kapo shouts at an old French woman lying down unable to get up and go to work, even though she is punished for what she tries to do:

Old inmate: Je suis malade.

[I am sick.]

Marta: Ona jest chora, nie może iść.

[She is sick, she cannot walk.]

Kapo: Czyś ty z byka spadła?

[Are you mad?]

[She hits Marta with a bludgeon.] (31'21-31'23). 


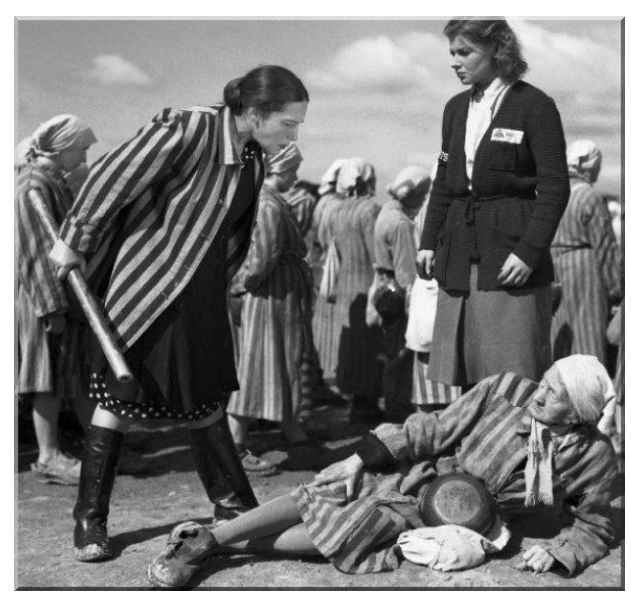

Figure 3: An old French inmate, Marta Weiss and the kapo, The Last Stage (1948)

Marta interprets the interrogation of a group of Yugoslav women soldiers and she manages to speak to them in Serbo-Croatian. She is also active to help the camp resistance, as shown in the following scene, at the entrance gate to the camp:

Inmate: Marta, słuchaj kochanie, zaraz przyjadą chłopcy, przywiozą różne rzeczy dla obozu. Chodzi o to, żebyś przeszkodziła, gdyby chciano skontrolować wóz. Jak myślisz uda się?

[Marta, listen, dear, our boys will arrive in a moment, they bring things for the camp. Could you retain [the guard] if he wants to search the car? Will you manage it?]

Marta: Musi się udać.

[This must work.]

[The guard arrives on a bicycle. A car approaches. Marta hits a telephone and puts the earpiece away.]

Marta calls the guard: Herr Rottenführer, guten Tag, Sie werden am telefon verlangt.

[Herr Rottenführer, good morning, there is a phone call for you.]

[The guard runs to the telephone.]

Marta [to the inmates on the car]: Jazda, jazda, szybko!

[Come on, come on, quick!]

The guard: - Hallo, Hallo, Hallo, Hallo, Hallo!

Marta: Meldet sich niemand? Denn es war bestimmt nicht so wichtig!

[Is nobody answering? Then surely it wasn't so important!].

The guard: Verfluchte Scheiße!

[Damn shit!] (57'05-57'53).

Marta can move freely throughout the camp and she intercepts news about the actual situation at the front and about the imminent liquidation 
of the camp. The camp resistance orders her to escape with Tadek, a fellow inmate, to transmit to the world the valuable information about the camp. She is caught, and even during the interrogation she continues to interpret for Tadek what the German SS utters:

SS man: Was haben Sie davon?

[What do you make of it?]

Tadek: Nie rozumiem.

[I don't understand.]

SS man: Sagen Sie es ihm!

[Tell him!]

Marta: Pyta się co nam z tego przyszlo?

[He asks what good has come of that for us?]

SS man: Ich bekomme ja euch doch alle! Aber euch beiden tut es mir leid. Ihr seid so jung.

[I'll manage to cope with all of you. I am sorry for the two of you. You are so young.]

Marta: Mówi, że nas mu jest okropnie żal, bo jesteśmy tacy młodzi.

[He says he is very sorry because we are so young.]

SS man: Ich habe einen Vorschlag für euch. Sagt mir nur, wohin ihr diese Papiere gebracht habt, und ihr seid frei!

[I have a proposition for you. Tell me where you have taken the papers and you will be free.]

Marta: Mamy mu tylko powiedzieć dokąd zanieśliśmy papiery $i$ będziemy wolni.

[We must tell him where we have taken the papers, and we will be free.]

Tadek: Powiedz mu, że nic nie wiemy o żadnych papierach. A obietnicami może się dać wypchać!

[Tell him we know nothing about the documents. And he can get stuffed with his promises!]

Marta: Wir wissen nichts.

[We know nothing ](1'40'00-1'40'59). 


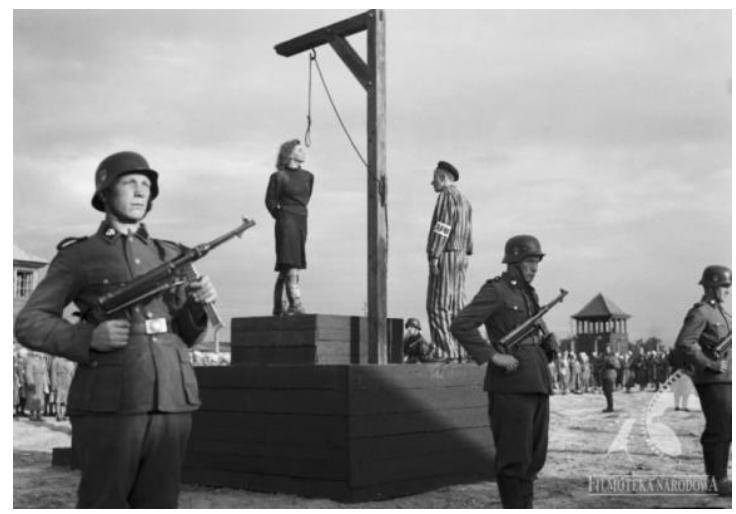

Figure 4: The execution of Marta Weiss, The Last Stage (1948)

The Last Stage also depicts two other groups of interpreters. The first one consists of inmates appointed as ad hoc interpreters. For example, Anna, the German prisoner, interprets from German into Polish the orders of the doctor in the camp hospital. There are also a group of SS guards who act sometimes as linguistic intermediaries during the administration of punishment.

As it has been pointed above, The Last Stage constitutes a seminal film in both Holocaust studies and feminist studies. However, this docudrama also presents a valuable contribution to translation and interpreting studies, in particular with reference to the role of translators and interpreters. Marta Weiss is more than a realistic figure of an interpreter in an extreme situation: she is an active and resistant heroine who enables us to comprehend the vile environment. She translates the words and at the same time she conveys the truth about the hostile world in which she and her fellow inmates are forced to live. Owing to her linguistic skills, she can defend them in front of their oppressors, and on many occasions she saves their lives. But she could not save herself. Her death, as the death of any linguistic intermediary in such violent circumstances, means a loss much more tangible than the death of any other person. This is why her death, as that of Mala Zimetbaum or of Władysław Baworowski constitutes the major memory of the concentration camp.

\section{Discussion and conclusions}

In this article, I have tried to describe interpreting in an aggressive monolingual environment involving terror and coercion as it is depicted in documentary, ontological narratives and in an artistic form filmed by an eye-witness at that time.

The recollections of former inmates as well as Jakubowska's film illustrate the complex role a camp interpreter had to play, faced as they were with tasks which went far beyond the neutral transfer of information from one language to another. Instead, it was often a matter involving the 
survival of an inmate or even the interpreter him- or herself. Władysław Baworowski, Mala Zimetbaum or other interpreters and translators recalled in the accounts of the concentration camp survivors as well as in the cinematic role of Marta Weiss acting as the Dolmetscher - performed a critically important role. The interpreter found him- or herself in the heart of a crisis which had a direct impact on their life and that of their fellow prisoners. This uneasy position as a go-between, acting in a space between the oppressors and the oppressed, and used as an instrument to convey horrific information related to life and death in the camp, or as a mouthpiece to issue degrading insults and humiliating orders, could bring out both the best and the worst in human behaviour.

As Cronin (2006) notes, the Lagerdolmetscher was a hostage to their own skills: they had no choice but to execute the task. At the same time, they could use their knowledge to influence their own life as well as the lives of others. This degree of influence, fraught with danger, has no parallel in the history of interpreting. Interpreters' and translators' role in such an extreme environment, their "potential" power and their active presence clearly defy the notion of impartiality or neutrality in the execution of their job.

\section{References}

APMA-B: The Auschwitz-Birkenau Memorial Museum Archives. Statements. Volumes 4, 8a, 9, 20, 21, 26b, 29, 33, 35, 36, 39, 45, 46, 47, 50, 61, 64, 65, $66,67,72,73,74,75,76,77,78,79,80,82,83,84,86,87,88 \mathrm{c}, 89,89 \mathrm{~b}, 91$, 94, 96, 97, 100, 101, 111, 114, 115, 122, 124.

APMA-B: The Auschwitz-Birkenau Memorial Museum Archives. Recollections. Volumes 131, 133, 136, 139, 145, 148, 149, 154, 167.

APMM: The Majdanek State Museum Archives. Statements. Volume VII-135.

Arciszewska, B. (2013). L'interprète dans les zones de conflit (unpublished master's thesis). University of Warsaw, Warsaw.

Arendt, H. (1963). Eichmann in Jerusalem: A report on the banality of evil. New York: The Viking Press.

Baker, M. (2005). Narratives to and of translation. SKASE Journal of Translation and Interpretation, 1(1), 4-13.

Baker, M., \& Maier, C. (Eds.). (2011). Ethics and the curriculum. Special Issue of The Interpreter and Translator Trainer, 5(1).

Balázs, B. (1987). Wybór pism. Warsaw: Wydawnictwo Artystyczne i Filmowe.

Bowen, D., \& Bowen, M. (1985). The Nuremberg Trials: Communication through translation. Meta, 30(1), 74-77.

Capelli, P. (2014). Wartime interpreting: Exploring the experience of interpreters and translators. In C. Valero Garcès (Ed.), (Re) conciderando etica e ideologia en situaciones de conflict/(Re)visiting ethics and ideology in situations of conflict (pp. 15-24). Alcalà de Henares: Servicios de Publicaciones Universidad de Alcalà. 
Cronin, M. (2006). Translation and identity. London: Routledge.

Dobosiewicz, S. (2000). W obronie życia i godności ludzkiej. Warsaw: Bellona.

Gaiba, F. (1998). The origins of simultaneous interpretation: The Nuremberg Trial. Ottawa, ON: University of Ottawa Press.

Gramling, D. (2012). Another unspeakability: Levi and Lagerszpracha. New German Critique 117, 39(3), 165-187.

Guidère, M. (2008). Irak in translation: De l'art de perdre une guerre sans connaître la langue de son adversaire. Paris: Édition Jacob-Douvernet.

Gunia, A. (2006). Język obozów koncentracyjnych. Języki Specjalistyczne, 6, 56-60.

Haas, N. (2011). Dolmetschen am Ruanda-Tribunal. Munich: Martin Meidenbauer.

Hale, S. (2007). Community interpreting. Hampshire: Palgrave Macmillan.

Haltof, M. (2012). Polish film and the Holocaust: Politics and history. New York: Berghahn.

Hollender, B. (1987). Spojrzenie wstecz. Ekran, 50, 14-15.

Kuhiwczak, P. (2007). The grammar of survival: How do we read Holocaust testimonies. In M. Salama-Carr (Ed.), Translating and interpreting conflict. (pp. 61-74). Amsterdam: Rodopi.

Levi, P. (1989). The drowned and the saved. New York: Vintage International. Transl. by Raymond Rosenthal.

Loewy, H. (2004). The Mother of all Holocaust films?: Wanda Jakubowska's Auschwitz Trilogy. Historical Journal of Film, Radio and Television, 24(2), 179-204.

Malak, H. M. (1961). Klechy w obozach śmierci. London: Veritas.

Monacelli, C. (2002). Interpreters for peace. In G. Garzone \& M. Viezzi (Eds.), Interpreting in the 21st century: Challenges and opportunities. (pp. 181-193). Amsterdam: John Benjamins.

Morris, R. (1998). Justice in Jerusalem: Interpreting in Israeli legal proceedings. Meta, 43(1), 110-118.

Musioł, T. (1971). Dachau 1939-1945. Opole: Instytut Śląski.

Rigano, G. (2015). L'interprete di Auschwitz. Milan: Ed. Guerini e Associati Spa.

Shelley, L. (1986). Secretaries of death: Accounts by former prisoners who worked in the Gestapo of Auschwitz. New York: Shengold.

Stahuljak, Z. (2000). Violent distortions: Bearing witness to the taste of wartime translators. TTR, 13(1), 37-51.

Stahuljak, Z. (2010). War, translations, transnationalism: Interpreters in and of the war (Croatia 1991-1992). In M. Baker (Ed.), Critical readings in translation studies. (pp. 391-414). London: Routledge.

Szymczukiewicz, M. (2005). L'inteprétation communautaire dans l'armée. Étude de cas: Missions polonaises de paix (Unpublished master's thesis). University of Warsaw, Warsaw.

Takeda, K. (2007). Sociopolitical aspects of interpreting at the International Military Tribunal for Far East (1946-1948) (Unpublished doctoral dissertation). Universitat Rovira i Virgilli, Tarragona.

Talarczyk-Gubała, M. (2015). Wanda Jakubowska od nowa. Warsaw: Wydawnictwo Krytyki Politycznej. 
Thomas, R. (1997). United Nations Military Observer Interpreting in a community setting. In S. E. Carr, R. P. Roberts, A. Dufour.\& D. Steyn (Eds.), The Critical Link: Interpreters in the Community. (pp. 249-257). Amsterdam/Philadelphia: J. Benjamins Publishing.

Tryuk, M. (2004). L'interprétation communautaire: Des normes et des rôles dans l'interprétation. Warsaw: TEPIS.

Tryuk, M. (2010). Interpreting in Nazi concentration camps during World War II, Interpreting, 12(2), 125-145.

Tryuk, M. (2012). 'Ty nic nie mów, ja będę tłumaczył': O etyce w thumaczeniu ustnym. Warsaw: WLS.

Tryuk, M. (2015). On ethics and interpreters. Frankfurt: Peter Lang.

Tryuk, M. (2016). Interpreters in the concentration camp of Majdanek (1941-1944). In M. Wolf (Ed.), Interpreting in Nazi concentration camps (pp. 115-133). New York: Bloomsbury.

Watanabe, T. (2009). Interpretation at the Tokyo War Crimes Tribunal: An overview and Tojo's cross examination, TTR, 12(1), 57-91.

Wesołowska, D. (1996). Stowa z piekła rodem. Lagerszpracha. Cracow: Oficyna Wydawnicza Impuls.

Wiegand, C. (2000). Role of the interpreter in the healing of a nation: An emotional view. In R. P. Roberts, S. E. Carr, D. Abraham, \& A. Dufour (Eds.), The critical link 2: Interpreters in the community. (pp. 207-218). Amsterdam: John Benjamins.

Wolf, A. (2011). Więźniowie funkcyjni. In M. Grudzińska (Ed.), Majdanek: Obóz koncentracyjny $w$ relacjach więźniów $i$ świadków (pp. 76-81). Lublin: Państwowe Muzeum na Majdanku.

Wolf, M. (2016) (ed.). Interpreting in Nazi concentration camps. New York: Bloomsbury.

\section{Filmography}

Ostatni Etap (The Last Stage), dir. Wanda Jakubowska, 1948, DVD, Poleart.

1 Volksdeutsche is a term used by the Nazis to describe ethnic Germans in term of race regardless of their citizenship.

2 All the quotations from the statements and the recollections of the former inmates have been translated from Polish into English by the author.

3 A docudrama is a genre of feature film or staged theatre which uses literary or narrative techniques to flesh the bare facts of an event to tell a story.

4 In camp jargon Muselmann is a term to refer to a prisoner suffering from starvation and exhaustion and who is resigned to his impending death. 